\title{
Study Objective Primary Indicator
}

National Cancer Institute

\section{Source}

National Cancer Institute. Study Objective Primary Indicator. NCI Thesaurus. Code C94091.

Specifies whether this is a main or principal study objective. 